ARTICLE

\title{
Orbital- and millennial-scale Antarctic Circumpolar Current variability in Drake Passage over the past 140,000 years
}

\author{
Shuzhuang Wu (1) ${ }^{1 凶}$, Lester Lembke-Jene (1) ${ }^{1}$, Frank Lamy (1) ${ }^{1}$, Helge W. Arz (D) ${ }^{2}$, Norbert Nowaczyk ${ }^{3}$, \\ Wenshen Xiao ${ }^{4}$, Xu Zhang (1) 5,6 H. Christian Hass ${ }^{7,14}$, Jürgen Titschack (10 ${ }^{8,9}$, Xufeng Zheng ${ }^{10}$, Jiabo Liu ${ }^{3,11}$, \\ Levin Dumm ${ }^{8}$, Bernhard Diekmann ${ }^{12}$, Dirk Nürnberg ${ }^{13}$, Ralf Tiedemann ${ }^{1} \&$ Gerhard Kuhn (i) ${ }^{1}$
}

The Antarctic Circumpolar Current (ACC) plays a crucial role in global ocean circulation by fostering deep-water upwelling and formation of new water masses. On geological timescales, ACC variations are poorly constrained beyond the last glacial. Here, we reconstruct changes in ACC strength in the central Drake Passage in vicinity of the modern Polar Front over a complete glacial-interglacial cycle (i.e., the past 140,000 years), based on sediment grain-size and geochemical characteristics. We found significant glacial-interglacial changes of ACC flow speed, with weakened current strength during glacials and a stronger circulation in interglacials. Superimposed on these orbital-scale changes are high-amplitude millennialscale fluctuations, with ACC strength maxima correlating with diatom-based Antarctic winter sea-ice minima, particularly during full glacial conditions. We infer that the ACC is closely linked to Southern Hemisphere millennial-scale climate oscillations, amplified through Antarctic sea ice extent changes. These strong ACC variations modulated Pacific-Atlantic water exchange via the "cold water route" and potentially affected the Atlantic Meridional Overturning Circulation and marine carbon storage.

\footnotetext{
${ }^{1}$ Alfred-Wegener-Institut Helmholtz-Zentrum für Meeres- und Polarforschung, Bremerhaven 27568, Germany. ${ }^{2}$ Leibniz Institute for Baltic Sea Research, Warnemünde, 18119 Rostock, Germany. ${ }^{3}$ Helmoltz Centre Potsdam GFZ German Research Centre for Geosciences, Potsdam 14473, Germany. ${ }^{4}$ State Key Laboratory of Marine Geology, Tongji University, Shanghai 200092, China. ${ }^{5}$ Key Laboratory of Western China's Environmental Systems, (Ministry of Education), College of Earth and Environmental Sciences, Lanzhou University, Lanzhou 730000, China. ${ }^{6}$ State Key Laboratory of Tibetan Plateau Earth System, Resources and Environment (TPESRE), Institute of Tibetan Plateau Research, Chinese Academy of Sciences, Beijing 100101, China. ${ }^{7}$ AlfredWegener-Institut Helmholtz-Zentrum für Meeres- und Polarforschung, Sylt 25980, Germany. ${ }^{8}$ MARUM-Center for Marine Environmental Sciences, University of Bremen, Bremen 28359, Germany. ${ }^{9}$ Senckenberg am Meer, Marine Research Department, Wilhelmshaven 26382, Germany. ${ }^{10}$ State Key Laboratory of Marine Resources Utilization in South China Sea, Hainan University, Haikou 570228, China. ${ }^{11}$ Southern University of Science and Technology, Department of Ocean Science and Engineering, Shenzhen 518055, China. ${ }^{12}$ Alfred-Wegener-Institut Helmholtz-Zentrum für Meeres- und Polarforschung, Potsdam 14473, Germany. ${ }^{13}$ GEOMAR, Helmholtz Centre for Ocean Research Kiel, Kiel 24148, Germany. ${ }^{14}$ Deceased: H. Christian Hass.

凶email: shuzhuangwu@gmail.com
} 
T he Antarctic Circumpolar Current (ACC) is the largest oceanic current system on Earth ${ }^{1}$. It represents the central distributor of globally important water masses, as it is intimately linked to the meridional overturning circulation cells of the adjoining Atlantic, Indian, and Pacific oceans. It connects wind-driven surface circulation and thermohaline deep and bottom water circulation with impacts on global salinity, nutrients, dissolved gasses, and heat transport ${ }^{1,2}$. The configuration of the frontal systems of the ACC with upwelling and downwelling cells is crucial for Antarctic climate, the modes of biological productivity, and the physical and biological carbon pump ${ }^{3,4}$. Understanding the magnitude and sensitivity of the ACC during the geological past is fundamental for assessing its role in the global Meridional Overturning Circulation (MOC), in particular with regard to ongoing and future anthropogenic climate change.

Restricted regional proxy evidence for changes in ACC flow speed on glacial-interglacial timescales has yielded heterogeneous results in the different sectors of the Southern Ocean ${ }^{5-12}$ (Supplementary Fig. 9). For example, most of the available subantarctic records from the Indian Ocean sectors ${ }^{9,11}$ of the ACC reveal enhanced glacial current speeds, which is contrasted by flow speed reconstructions in the subantarctic eastern South Pacific $^{8}$ and the subantarctic Atlantic sector ${ }^{13}$ with decreased flow (Supplementary Fig. 9). High-resolution reconstructions of the ACC flow speed at the entrance of Drake Passage (MD07-3128) and on its northern continental slope (MR0806-PC09) extend only back to $\sim 65 \mathrm{ka}$ but show substantial glacial decreases ${ }^{6}$. In contrast, time-slice reconstructions from the Scotia Sea downstream of the Drake Passage show only small flow speed changes for the Last Glacial Maximum (LGM) compared to the Holocene $^{5}$. Knowledge for the ACC changes in the central Drake Passage beyond the last glacial cycle is still unclear. Furthermore, underlying forcing mechanisms remain largely elusive ${ }^{5-8}$. At present, the ACC strength is mainly driven by the southern westerly winds (SWW) and surface buoyancy forcing ${ }^{14,15}$. Previous studies proposed that sea ice cover, in addition to wind stress, has a significant influence on the surface ocean drag coefficient on forcing the ocean surface layer and ultimately current speed $5,6,16$.

The Drake Passage is the major "bottleneck" (Fig. 1) along the eastward ACC path around Antarctica, subdivided by three principle oceanographic fronts: the Subantarctic Front (SAF), the Polar Front (PF), and the Southern ACC Front (SACCF $)^{17}$. Subsidiary fronts were further determined by satellite altimetry showing multiple jets along the ACC pathway ${ }^{18}$. The ACC transports cold and fresh water from the Pacific to the Atlantic through the Drake Passage, known as "cold water route"19. This cold water route complements the warm westward Agulhas Current or "leakage" off the Cape of Good Hope known as "warm water route". These two sources, together with deep waters originating from the Southern Ocean, comprise the northwardflowing return path balancing the southward migration of the Circumpolar Deep Water component of the Atlantic Meridional Overturning Circulation (AMOC) $)^{1,2,19-21}$.

In this work, we reconstruct changes in Pacific-Atlantic ACC flow speed on millennial to glacial-interglacial time scales over the past $140 \mathrm{ka}$. We used high-resolution grain-size data of the siliciclastic sediment fraction and X-ray fluorescence (XRF) scanning-based elemental ratios from a sediment core in the central Drake Passage (Site PS97/085; $58^{\circ} 21.28^{\prime} \mathrm{S}, 62^{\circ} 10.02^{\prime} \mathrm{W}$; $3090 \mathrm{~m}$ water depth; Fig. 1) as bottom flow speed proxies. The age model is based on a combination of paleomagnetic excursions, relative paleointensity (RPI), radiocarbon dates, and tuning of high-resolution XRF scanning-derived calcium to titanium ratios $(\ln (\mathrm{Ca} / \mathrm{Ti}))$ to Antarctic temperature anomalies (see Supplementary Methods; Supplementary Table 1). Linear sedimentation rates range between $\sim 2$ and $40 \mathrm{~cm} / \mathrm{ka}$, with higher mass accumulation rates during full glacial periods (Supplementary Fig. 3). In addition, we extend a previously published diatom-based winter sea ice record from the Scotia Sea further back in time to

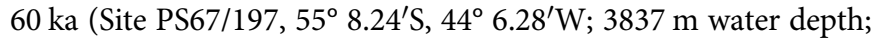
Fig. 1$)^{22}$. The chronology of this latter core has been published before and is used here without modification ${ }^{23}$. Combining our ACC flow speed proxies with sea-ice reconstructions enables us to investigate millennial-scale ACC variations, potentially linked to Antarctic winter sea ice changes during the last glacial period.

\section{Results and discussion}

ACC flow speed proxies for the Drake Passage. We use changes in grain size and geochemical properties of the terrigenous sediment fraction to reconstruct changes in ACC strength (Fig. 2). The linear function between sortable silt mean grain sizes $(\overline{\mathrm{SS}}, 10-63 \mu \mathrm{m})$ and scalar bottom current velocities is typically applied for evaluating relative changes in the near-bottom velocities in deep-sea sediments ${ }^{24,25}$. We correlated near-bottom velocities mooring measurements with $\overline{\mathrm{SS}}$ of seafloor sediments on a north-south Drake Passage transect ${ }^{26}$. However, modern observations ${ }^{27}$ reveal that ACC flow speeds at $\sim 3000 \mathrm{~m}$ water depth can reach up $40-60 \mathrm{~cm} \mathrm{~s}^{-1}$; such high flow speeds at the sea floor can potentially remove parts of the silt and even the sand fractions ${ }^{24}$. The grain-size distribution mode would thus shift to the coarser fractions dominated by fine sand (Supplementary Fig. 4, see Supplementary Methods), and hence impair the $\overline{S S}$ as a current speed proxy. Accordingly, the $\overline{\mathrm{SS}}$ may not capture the entire magnitude of the flow-speed variations in our record (Fig. 2d, see Supplementary Methods). High ACC speed can extend the sorting range beyond the sand-silt boundary (Supplementary Fig. 4), which was also observed at the Chilean Margin and the northernmost Drake Passage ${ }^{6}$ (Supplementary Fig. 8). Therefore, we use the mean grain size of the sortable silt plus the fine sand fractions ( $\overline{\mathrm{SSFS}}, 10-125 \mu \mathrm{m}$ ) as flow-speed proxy to reconstruct deep ACC dynamics throughout the past $140 \mathrm{ka}$ (Fig. 2e). Since our site is $\sim 400 \mathrm{~km}$ away from the South American continent and Antarctica, the terrigenous sand fractions are most likely transported by various processes (including sea ice, icebergs, etc.) from the continents and then reworked by bottom currents. Generally, unsorted ice-rafted debris (IRD) might affect the $\overline{\text { SS}}$-based flow speed proxy ${ }^{28}$. However, the content of IRD in our sediment record is generally less than 2 vol. $\%$ and 25 clasts $\mathrm{cm}^{-3}$ (Supplementary Fig. 5). One spike with $\sim 18$ vol.\% at the end of Marine Isotope Stage (MIS) 4 might overestimate large clasts (see Supplementary Methods). IRD fluctuations are overwhelmingly independent of $\overline{\text { SSFS }}$ changes with short-term exceptions at 22-24 ka and in the oldest part beyond $\sim 134$ ka (Supplementary Fig. 5). Furthermore, variations in SSFS and SSFS\% component are positively correlated $\left(r^{2}=0.8\right.$; Supplementary Fig. 5), suggesting bottom currents are the principal driver for changes in the grain-size fraction $(10-125 \mu \mathrm{m})$ at our site $^{24,28}$.

Zirconium ( $\mathrm{Zr})$ is typically accumulating in the heavy mineral fraction associated with the sand fractions, especially fine sand $(63-125 \mu \mathrm{m})$, while rubidium $(\mathrm{Rb})$ is preferentially retained in the clay mineral faction ${ }^{29}$. Previous studies found a positive correlation between grain size and the $\mathrm{Zr} / \mathrm{Rb}$ ratio ${ }^{30,31}$. In case, where the depositional regime is dominated by current sorting, the $\ln (\mathrm{Zr} / \mathrm{Rb})$ ratio can indicate bottom current strength ${ }^{31}$. Our record shows a positive correlation between $\overline{\mathrm{SSFS}}$ and $\ln (\mathrm{Zr} / \mathrm{Rb})$ ratios $\left(r^{2}=0.6, n=1480\right)$. Major aeolian input can be ruled out in our study area by clay mineralogy and geochemical properties $^{26,32,33}$. High-resolution records of grain size and $\mathrm{Zr} /$ $\mathrm{Rb}$ ratios can thus provide a robust signature of ACC variability. 


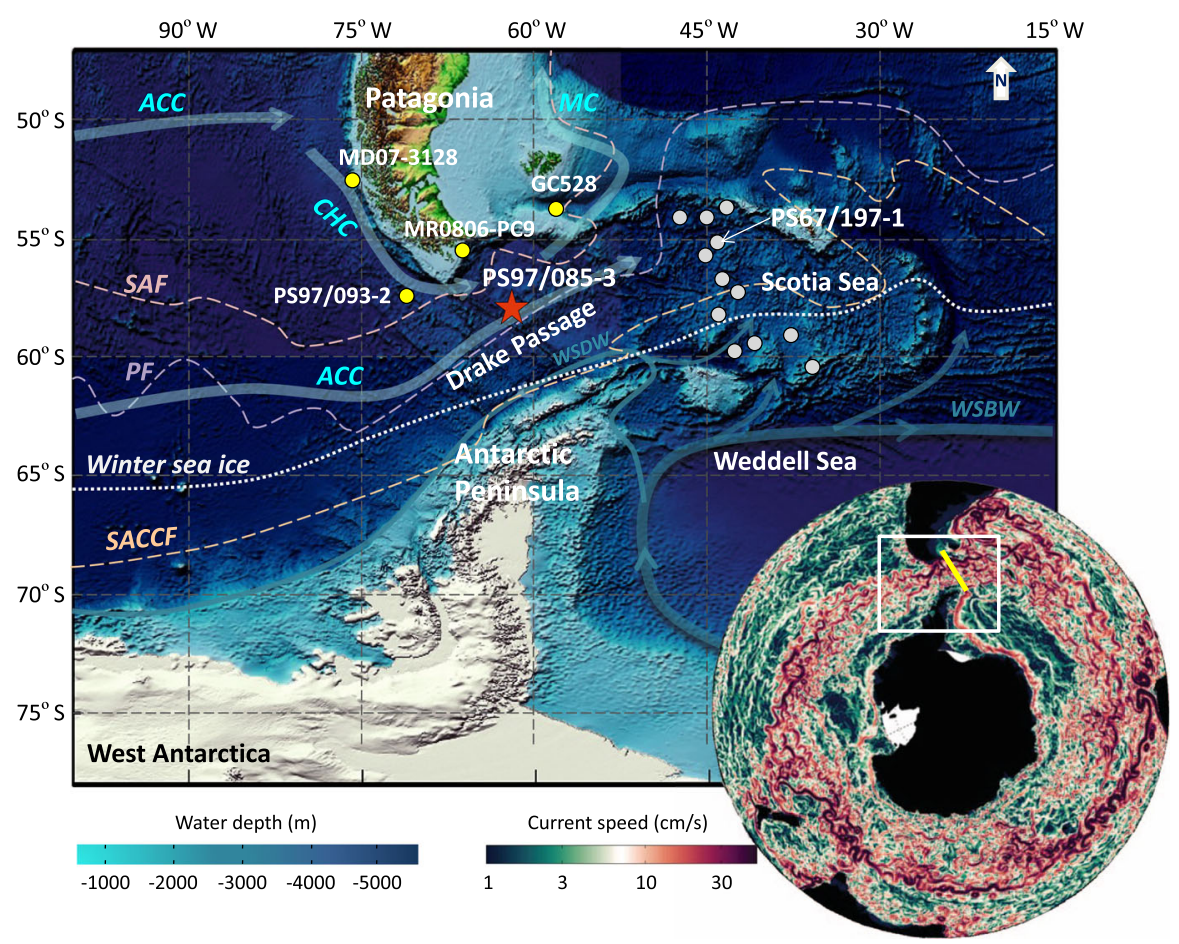

Fig. 1 Location map. Core PS97/085-3 is located in the central Drake Passage (red star), 40 km north of the Polar Front (see Supplementary Fig. 1). Yellow dots mark sediment cores north of the Subantarctic Front ${ }^{6-8}$. Gray dots indicate Scotia Sea transect cores south of the Polar Front ${ }^{5}$. Core PS67/1971 in the Scotia Sea is sensitive to changes in winter sea ice extent ${ }^{22}$. Light blue arrows show the Antarctic Circumpolar Current (ACC), the Cape Horn Current $(\mathrm{CHC})$ and Malvinas Current $(\mathrm{MC})^{64}$, while dark green-blue arrows denote Weddell Sea Bottom Water (WSBW, thick) and Weddell Sea Deep Water (WSDW, thin) flows. The white dotted line marks the average modern winter sea ice edge ${ }^{68}$. Dashed lines are the Subantarctic Front (SAF, pink), Polar Front (PF, purple) and the Southern Antarctic Circumpolar Current Front (SACCF, orange) ${ }^{17}$. The right bottom insert map is modified from Rintoul. $(2018)^{2}$ shows current speed in the Southern Ocean, with warmer red colors representing higher current speeds. The white box shows the study area and the yellow line marks the Jason Track $104^{36}$. The figure is adapted from Wu et al. ${ }^{26}$.

Changes in ACC strength in the central Drake Passage. Our sediment record reveals glacial-interglacial variations in ACC flow speed in the central Drake Passage over the past $140 \mathrm{ka}$ (Fig. 2). The timing of major ACC changes follows Antarctic temperature variations ${ }^{34}$, implying the ACC strength in the Drake Passage is sensitive to large-scale Southern Hemisphere climate oscillations (Fig. 2a, c, e). The last interglacial (MIS 5e, $\sim 129-116 \mathrm{ka}$ ) was warmer than today ${ }^{35}$ and our record indicates average $\overline{\mathrm{SSFS}}$ of $\sim 48 \mu \mathrm{m}$. During the stable part of MIS 5e ( 123-118 ka), our record shows a plateau structure with average SSFS of $\sim 52 \mu \mathrm{m}$, which is higher than the Holocene average $(\sim 0-12 \mathrm{ka}, \sim 45 \mu \mathrm{m})$ within measurement uncertainty (Fig. 2e). This suggests that the ACC flow speed was enhanced during MIS $5 e$, supported by corresponding changes in $\ln (\mathrm{Zr} / \mathrm{Rb})$ ratios during the stable MIS 5e ( 1.73) and the Holocene ( 1.65) (Fig. 2c). In contrast to MIS $5 \mathrm{e}$ and the Holocene, the ACC strength significantly decreased during the Penultimate Glacial Maximum (PGM, $\sim 140 \mathrm{ka} ; \overline{\mathrm{SSFS}}=\sim 27 \mu \mathrm{m})$ and the LGM sensu lato $(\sim 28-18 \mathrm{ka} ; \overline{\mathrm{SSFS}}=\sim 32 \mu \mathrm{m})$. Given the correlation between the $\overline{\text { SSFS }}$ and adjacent current meter, the calculated mean bottom current speeds vary from $\sim 6$ to $20 \mathrm{~cm} \mathrm{~s}^{-1}$ in the center of the Drake Passage during the last glacial cycle (Fig. $2 \mathrm{f}$ and Supplementary Fig. 6). The record shows a $\sim 8 \mathrm{~cm} \mathrm{~s}^{-1}$ increase in the ACC from the PGM to MIS 5e, larger than the LGM to Holocene increase of $\sim 5 \mathrm{~cm} \mathrm{~s}^{-1}$. High-frequency variability in millennialscale ACC changes prevailed during the glacial periods, but the ACC flow speed maxima always remained below $\sim 15 \mathrm{~cm} \mathrm{~s}^{-1}$ during this interval (Fig. 2f). Noteworthily, the calculated flow speeds are depending on the sensitivity of the SSFS to the ACC flow speed that largely may rely on local conditions like bathymetry and seafloor morphology. Standard deviation of modern hourly current measurements is $8.2 \mathrm{~cm} \mathrm{~s}^{-1}$ at Site $\mathrm{C} 18^{27}$ which is similar to the PGM-MIS 5e amplitude (Fig. 3). Therefore, large uncertainties of about $50 \%$ of the calculated values thus exist owing as well to sparsely long-term measured data (see Supplementary Methods). A more reliable quantification of the ACC in the Drake Passage would require long-term current meter records, which are presently not available, and at sites where grain-size measurements exist or will be studied.

Here, we combine our records with published grain size data ${ }^{5-8}$ transferred by the latest calibration ${ }^{26}$ to explore glacial-interglacial changes in ACC strength associated with oceanic fronts in the Drake Passage region (Fig. 3; Supplementary Table 2). Larger glacial-interglacial changes in flow speeds were observed north of the SAF with a range of $\sim 5-13 \mathrm{~cm} \mathrm{~s}^{-1}$ (MD07-3128, MR0806PC9, and GC528) at intermediate water depths $(\sim 600-1030 \mathrm{~m})^{6,7}$. Smaller fluctuations in ACC changes $\left(\sim 2 \mathrm{~cm} \mathrm{~s}^{-1}\right.$, PS97/093-2) occurred in deep water $(\sim 3781 \mathrm{~m})$ near the $\mathrm{SAF}^{8}$. In the central Drake Passage $\sim 40 \mathrm{~km}$ north of the PF, the ACC flow speeds exhibit a $\sim 5-8 \mathrm{~cm} \mathrm{~s}^{-1}$ glacial reduction at $\sim 3090 \mathrm{~m}$ water depth, which is considerably greater than variations along the Scotia Sea transect south of the PF $\left(<2 \mathrm{~cm} \mathrm{~s}^{-1}\right.$, Scotia Sea transect cores, $\sim 2000-4300 \mathrm{~m}$ water depth $)^{5}$. Differences between these glacialinterglacial changes are likely due to the geographical settings within latitudinal subdivisions of the ACC and the related fronts (Fig. 3). Therefore, we suggest an enhanced sensitivity of the ACC to glacial-interglacial climate changes around the $\mathrm{PF}$ and the $\mathrm{SAF}^{6-8}$, in contrast to minimal changes south of the PF along the Scotia Sea transect ${ }^{5}$. Such presumption would be consistent with modern ACC volume transport and highest current velocities 


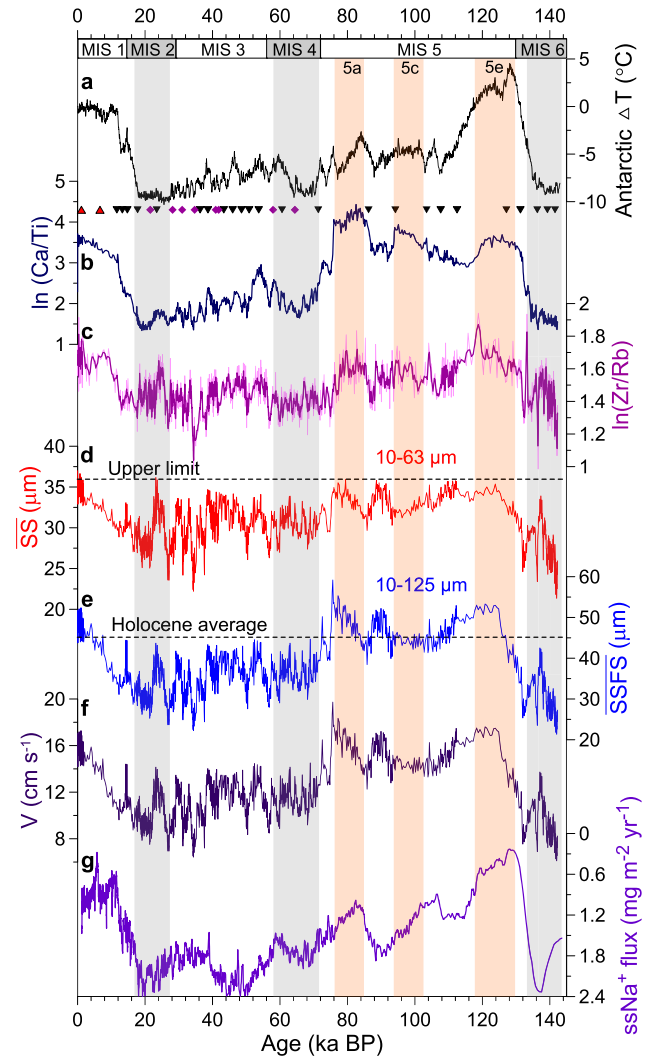

Fig. 2 Reconstructed changes in ACC strength and compared with Antarctic temperature and Southern Ocean sea-ice extent. a Antarctic temperature changes from the European Project for Ice Coring in Antarctica (EPICA) Dome C ice core ${ }^{47}$. b High-resolution XRF scanner-derived records of $\ln (\mathrm{Ca} / \mathrm{Ti}$ ) (peak area count ratios; black triangles) were applied to finetune the Antarctic temperature anomalies together with radiocarbon dates (red triangles), relative paleointensity and paleomagnetic excursions (purple diamonds) age control points from core PS97/085-3 (see Supplementary Methods, Supplementary Figs. 2 and 3). c XRF-derived In $(\mathrm{Zr} / \mathrm{Rb})$ variations indicate changes in sediment grain-size fractions. $\mathbf{d}$ Mean sortable silt grain size $(\overline{\mathrm{SS}}, 10-63 \mu \mathrm{m})$ reaches up its upper limit under high flow speeds. e Mean grain size of sortable silt and fine sand ( $\overline{\mathrm{SSFS}}, 10-125 \mu \mathrm{m}$ ) was used as the ACC flow speed proxy in this study. $\mathbf{f}$ ACC bottom flow speeds were estimated by the correlation between the $\overline{\text { SSFS }}$ and adjacent current meter data (see Supplementary Fig. 6). g Sea salt sodium ( $\mathrm{ssNa} \mathrm{Na}^{+}$) flux from the EPICA Dronning Maud Land (EDML) ice core, a proxy for sea ice extent and atmosphere changes, smoothed with a three-points running mean ${ }^{34}$. Vertical gray bars mark inferred glacial periods and pink bars indicate the sub-interglacial during Marine Isotope Stage (MIS) 5 .

prevailing within the multiple jets of the SAF and PF in the Drake Passage region $18,27,36$.

Several processes might cause these changes in the ACC strength at site PS97/085, including changes in the strength and latitudinal position of $\mathrm{SWW}^{14}$, oceanic frontal shifts ${ }^{37}$, and buoyancy forcing ${ }^{15}$. Although the intensity and position of the glacial SWW remain uncertain, a northward displacement of the SWW is widely assumed during the $\mathrm{LGM}^{38,39}$, with reduced impact on the ACC in the Drake Passage $e^{5,6,8}$. The glacial oceanic fronts were likewise suggested to have shifted equatorward ${ }^{37}$, thus the South American continent would have obstructed the ACC flow through the Drake Passage ${ }^{7}$. Moreover, changes in ACC strength on the glacial-interglacial timescale correspond to the sea salt sodium (ssNa) flux record from the East Antarctic Dronning Maud Land (EDML) ice core (Fig. 2e-g), a proxy partially related

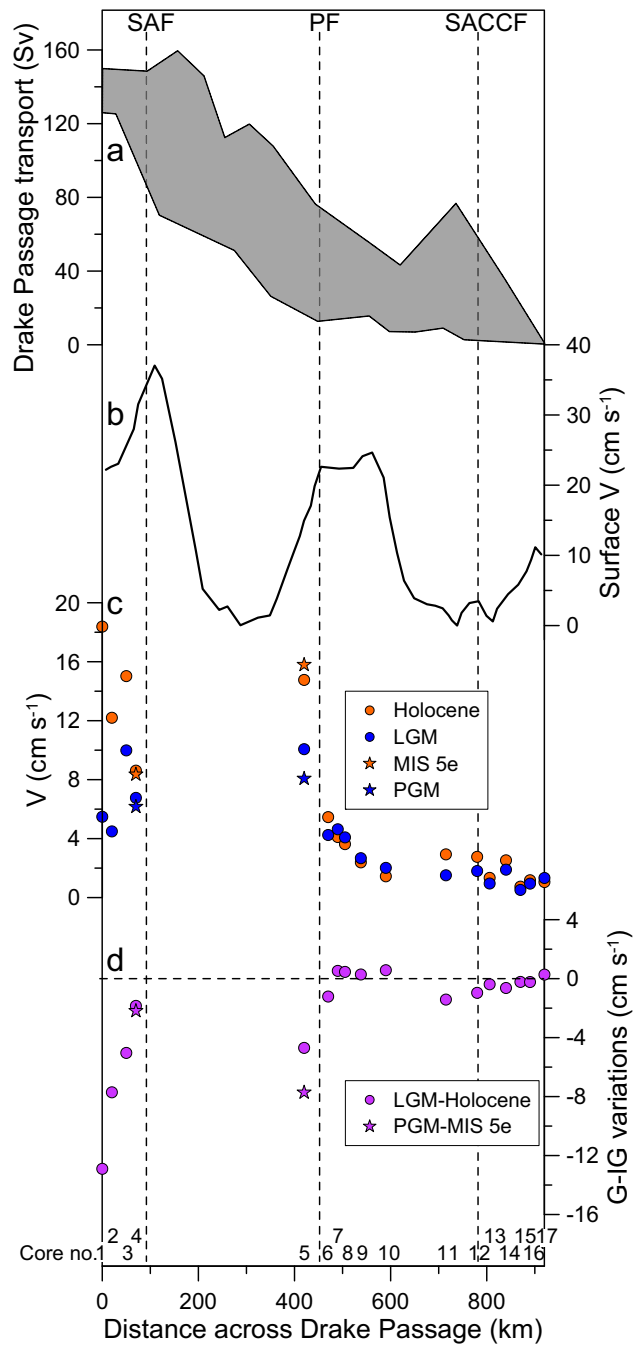

Fig. 3 Comparison of the ACC flow speeds in the Drake Passage region. a Range of modern Drake Passage cumulative volume transport from south to north along Jason Track $104^{36}$ and SR1b ${ }^{69}$. b Mean cross-track surface geostrophic velocities ${ }^{36}$. c Bottom flow speeds are transferred by the latest calibration in the Drake Passage region ${ }^{26}$ and the new SSFS flow speed proxy explained in Supplementary Fig. 6. Orange and blue dots mark ACC flow speeds during the Holocene and $\mathrm{LGM}^{5-8}$, respectively. Orange and blue stars indicate flow speed in the Drake Passage during the MIS $5 \mathrm{e}$ and PGM, respectively. d Glacial-interglacial (G-IG) flow speed differences associated with frontal system. Larger glacial reductions of flow velocities are detected in north of the SAF (cores 1-4, see Table S2) ${ }^{6-8}$ and the PF (core 5, this study) compared to small changes south of the PF (cores 6-17; ${ }^{5}$ see Supplementary Table 2). SAF Subantarctic Front, PF Polar Front, SACCF southern ACC Front.

to large-scale sea ice production ${ }^{34}$. This indicates that major changes in circum-Antarctic sea ice cover might have been linked to glacial-interglacial ACC strength changes, in line with earlier suggestions ${ }^{5,6}$. During the LGM, summer sea ice extent likely expanded northward by at least $\sim 500-\mathrm{km}^{37,40}$. Such large sea ice coverage could have significantly decreased the efficiency of wind stress acting on the ocean surface $5^{5,6,16}$ and thus reduced the ACC strength (Figs. $2 \mathrm{f}$ and $3 \mathrm{c}$ ). Conversely, at interglacial stages, sea ice retreat and southward displacement of the SWW and oceanic fronts would have increased wind stress efficiency on the ocean surface and accelerated the ACC speed ${ }^{5,6,22}$. However, the suborbital ACC changes in our record are not evident in the ss $\mathrm{Na}$ flux pattern, e.g., during late MIS 5, MIS 3 and 2 (Fig. 2e-g). We 


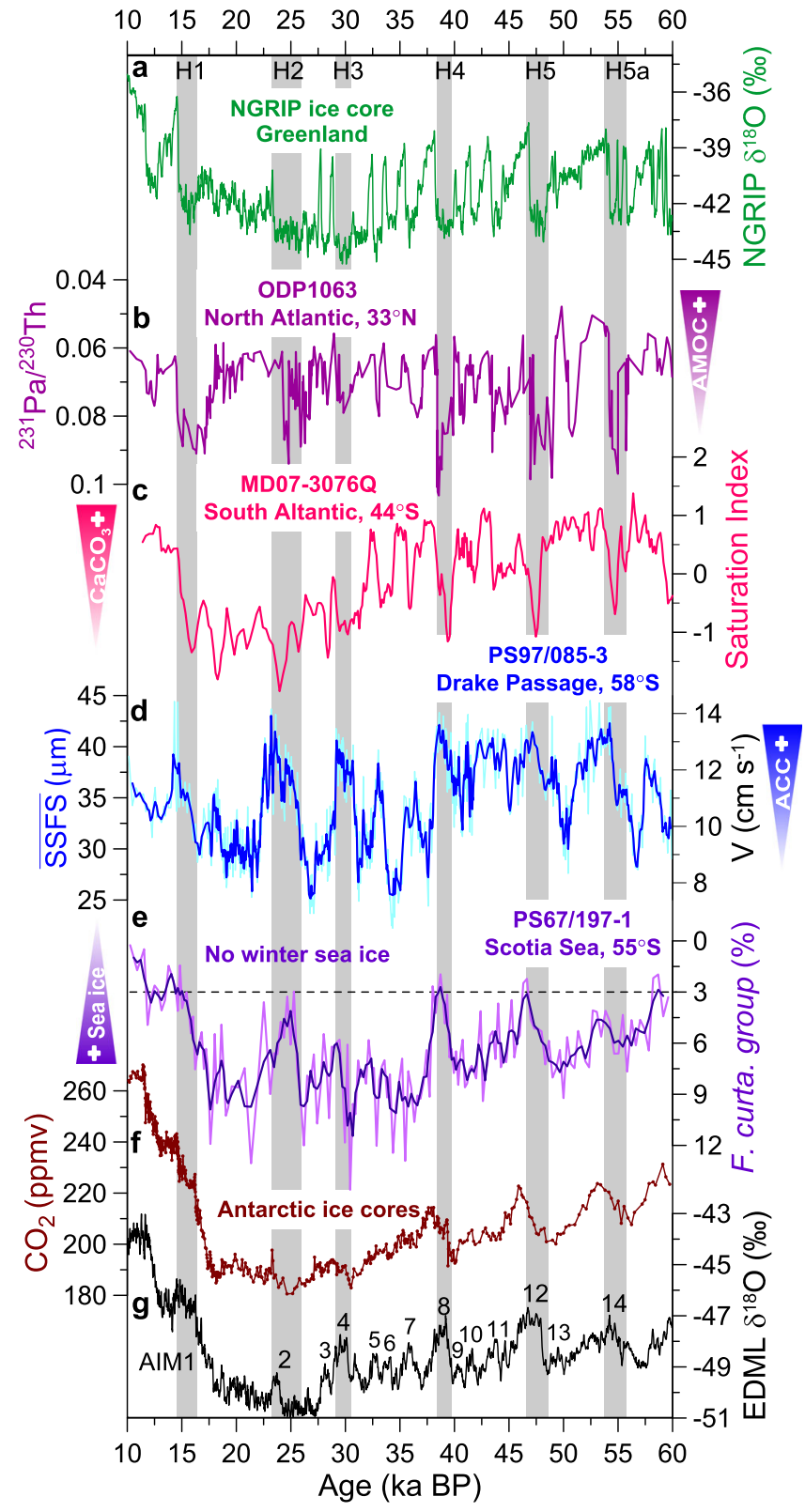

Fig. 4 Millennium-scale changes in ACC strength compared to paleoclimatic records over the last $\mathbf{6 0} \mathbf{k a}$. a Oxygen isotope record from North Greenland Ice Core Project (NGRIP, $\delta^{18} \mathrm{O}$ vs. VSMOW) ${ }^{70}$. b Bermuda Rise ${ }^{231} \mathrm{~Pa} /{ }^{230}$ Th proxy for the $\mathrm{AMOC}$ strength ${ }^{44,59,60}$. c Saturation index as a proxy for reconstructed carbonate saturation changes in the South Atlantic ${ }^{49}$. d $\overline{\text { SSFS }}$ as flow speed proxies for the current strength (threepoint smoothing, this study) and the transferred ACC flow speeds. e Relative abundance of diatom winter sea ice indicator Fragilariopsis curta group ( $F$. curta $+F$. cylindrus) with three-point smoothing22,67. The group abundance $>3 \%$ indicates the presence of winter sea ice 22,67 . $\mathbf{f}$

Synchronized ice-core atmospheric $\mathrm{pCO}_{2}{ }^{45} \cdot \mathbf{g} \delta^{18} \mathrm{O}$ time series from the EDML ice core ${ }^{45}$. Vertical gray bars mark inferred millennial-scale ACC peaks that correspond with millennial-scale temperature maxima in Antarctica (AIM) and Heinrich events (H) in Greenland.

speculate that the ssNa flux in the EDML ice core may not have captured short-term regional changes in sea ice extent, but was influenced by changes in the hydrologic cycle as well ${ }^{34,41}$.

Millennial-scale variations of ACC during the last glacial. Superimposed on the glacial-interglacial changes, our records exhibit marked high-amplitude, millennial-scale variations in the ACC flow speeds covering the last glacial cycle with highest amplitudes between MIS 4 and MIS 2 (Fig. 4d). Overall, a stronger ACC coincides with a weakened AMOC during cold phases in the Northern Hemisphere and warm intervals in the Southern Hemisphere (Fig. 4a, b, d). This pattern is consistent with the bipolar temperature seesaw and a strong atmospheric link between the North Atlantic realm across the tropics into the SWW system and subsequently also the $\mathrm{ACC}^{42,43}$. For the last glacial termination, the AMOC shutdown ${ }^{44}$ during Heinrich Event 1 reinforced the insolation-driven initial Southern Hemisphere deglacial warming ${ }^{45}$. Together with the previous records ${ }^{6}$, our data indicate that the ACC might play an important role in atmosphere-ocean changes and the interplay between millennialand orbital-scale changes during glacial terminations. Furthermore, we found increasing amplitudes of ACC millennial-scale variations as the climate was approaching the LGM $(\sim 38-23 \mathrm{ka}$; Fig. 4d), in contrast to a steady decline of the Antarctic temperatures (Fig. 4g). Enhanced sensitivity of the ACC towards the LGM was also recorded in the variation of the fine sand fraction percentages in the northern ACC/Cape Horn Current ${ }^{6}$ (Supplementary Fig. 8). This suggests the ACC reached its highest sensitivity to Southern Hemisphere millennial-scale climate oscillations during full glacial conditions, with the ACC reaccelerating to higher flow speeds during Antarctic warming events associated with Northern Hemisphere Heinrich Stadials ${ }^{46}$.

Supporting evidence for causes of millennial-scale ACC strength changes near our site is scarce. While regional temperature proxy records from Antarctica ${ }^{47}$ and off southernmost South America ${ }^{7,48}$ show some correspondence to our ACC strength reconstruction, remaining dissimilarities indicate that factors other than temperature changes played a role in forcing ACC flow variations. Previous ACC strength reconstructions from sites north of our location attributed variations to $\mathrm{SWW}^{6}$ changes associated northward shifts of the SAF ${ }^{7}$. However, model simulations of millennial-scale SWW changes indicate relatively small-scale variations during glacial periods ${ }^{49}$, which alone may have been insufficient to drive high-amplitude changes in ACC speeds from surface to $3090 \mathrm{~m}$ water depth (Fig. 4d). We thus chose to investigate potential regional amplification effects of sea ice changes on millennial-scale ACC dynamics, as the EDML ssNa flux did not indicate hemispheric-wide sea ice variations ${ }^{34}$ on these time-scales.

We reconstructed winter sea ice extent from diatom assemblages in a temporally well-resolved sediment record from the northern Scotia Sea, downstream of Drake Passage (PS69/197-1, Fig. 4e). Within age uncertainties, we observe a close correspondence between millennial-scale maxima in ACC strength and major winter sea ice retreat intervals (Fig. 4 d, e). Such sizeable variability of seasonal sea ice is also documented in other diatom records from the Scotia Sea, which revealed seasonal sea ice shifts by up to $\sim 8^{\circ}$ latitude that have been attributed to changes in regional sea surface temperatures, and austral summer insolation forcing ${ }^{50}$. Likewise, under modern conditions winds play a major control on the extent of sea-ice ${ }^{51}$. We propose that Antarctic sea ice extent, together with wind changes, acted as a positive feedback mechanism on increasing amplitudes in millennial-scale ACC strength towards the LGM. Sea ice effectively moderates the momentum transfer of wind-derived energy into the surface ocean ${ }^{5,16}$, because the air drag over ice and open water fundamentally differs and scales with the density of sea ice cover. The effect of sea ice on the flow depends on the ratio of ice floes to patches of open water ${ }^{5,16,52}$. In the dynamic Drake Passage, a highly mobile sea ice cover with an optimal concentration (50-90\%) would constitute a strong catalyst between wind and the surface ocean ${ }^{16,52}$. Such optimal sea ice conditions could increase the air-sea drag coefficient by a factor of two to 
four ${ }^{16,52}$, thus yield a strong amplification of glacial millennial-scale variations in SWW forcing on the ocean surface. We hypothesize that increasing amplitudes in millennial-scale ACC flow speed variations approaching the LGM have been likely linked to variations of Antarctic sea ice extent.

Changes in ACC strength could have regulated the PacificAtlantic exchange and caused variations in the chemical ventilation of the Drake Passage and South Atlantic water masses. On glacial-interglacial timescales, a weaker ACC in combination with a more extensive sea ice cover likely resulted in more sluggish deep waters and a stratified glacial circulation mode with a more isolated lower cell as detected by specific $\mathrm{Nd}$ isotope values in deep-sea corals ${ }^{53}$ and $\mathrm{Pb}$ - and $\mathrm{Nd}$-isotopic composition of authigenic $\mathrm{Fe}-\mathrm{Mn}$ oxyhydroxide sediment coatings ${ }^{54}$. A comparison of our ACC strength record to a high resolution carbonate saturation reconstruction from the Subantarctic South Atlantic ${ }^{49}$ indicates a correspondence of stronger ACC with reduced carbonate saturation during the major Antarctic warm intervals (Fig. 4b-d). These changes in inflow of Pacific-type deep-water masses likely influenced the carbonate chemistry in the subantarctic South Atlantic competing with North Atlantic sourced-deep waters at millennial time-scales ${ }^{49,55}$. The contribution of Antarctic Bottom Water circulation to the modern ACC is modest, but potentially increased during glacial periods when expanded sea ice favored its production and increased its salinity ${ }^{12,40}$. In combination with wind-driven upwelling ${ }^{42}$ and changes in sea-ice extent ${ }^{40,53,56}$ these Southern Ocean processes modulate sequestered $\mathrm{CO}_{2}$ exchange (Fig. 4f) with the atmosphere over millennial timescales.

Physical changes in the ACC linked to the AMOC stability. Changes in ACC transport through the cold water route, together with the Agulhas leakage via the warm water route, have been suggested to regulate the AMOC strength ${ }^{6,20,21}$. However, the relative contribution of these two water routes for the upper branch of AMOC has rarely been addressed in the past ${ }^{20,57}$. We compared our Drake Passage throughflow strength (Fig. 5d) with the Agulhas leakage intensity, reconstructed from planktic foraminiferal fauna census counts ${ }^{58}$ in the South Africa margin over the past $140 \mathrm{ka}$ (Fig. $5 \mathrm{c}$ ). Both water routes' transport increased during the past two deglaciations ${ }^{58}$ (Fig. $5 \mathrm{c}, \mathrm{d}$ ), suggesting that they both likely have induced a positive feedback to the AMOC recovering into a stronger interglacial mode as indicated by low ${ }^{231} \mathrm{~Pa} /{ }^{230} \mathrm{Th}$ ratios ${ }^{44,59,60}$ (Fig. 5b).

The Agulhas leakage reached its transient transport maximum during the terminations, with subsequently significantly decreased water volume transport to the South Atlantic $(\sim 8 \mathrm{~Sv}$ during MIS 5) during interglacials ${ }^{61}$. In contrast, the Drake Passage throughflow remained strong throughout MIS 5, with smaller sub-interglacial fluctuations (Fig. 5d). Extremes in total ACC volume transport were estimated over some weeks during a 20 -year period with maximum $166 \mathrm{~Sv}$ and minimum $105 \mathrm{~Sv}$ and a mean of $140 \mathrm{~Sv}^{62}$. Reanalysis for a 25 years observation period provides mean total transport volume through Drake Passage of $155 \pm 3 \mathrm{~Sv}^{63}$ and $\sim 62 \%$ of subsurface water $(50-1554 \mathrm{~m}$, float depth) is flowing into the Malvinas Current ${ }^{64}$. Therefore, for our maximum velocity calculations during peak warm interglacials like MIS 5e we assume a total volume transport through Drake Passage of about $166 \mathrm{~Sv}$. Relative glacial decrease (in \% of interglacial values) of bottom water flow velocities show a mean reduction of $43 \pm 19 \%$ (Fig. 3d, Supplementary Table 2) north of the PF. Therefore, we estimate an equivalent reduction for the ACC volume transport during glacial periods delivering $88 \pm 29$ Sv. The changes south of the PF are small and were not considered for this estimation (see Fig. 3d). Our record show

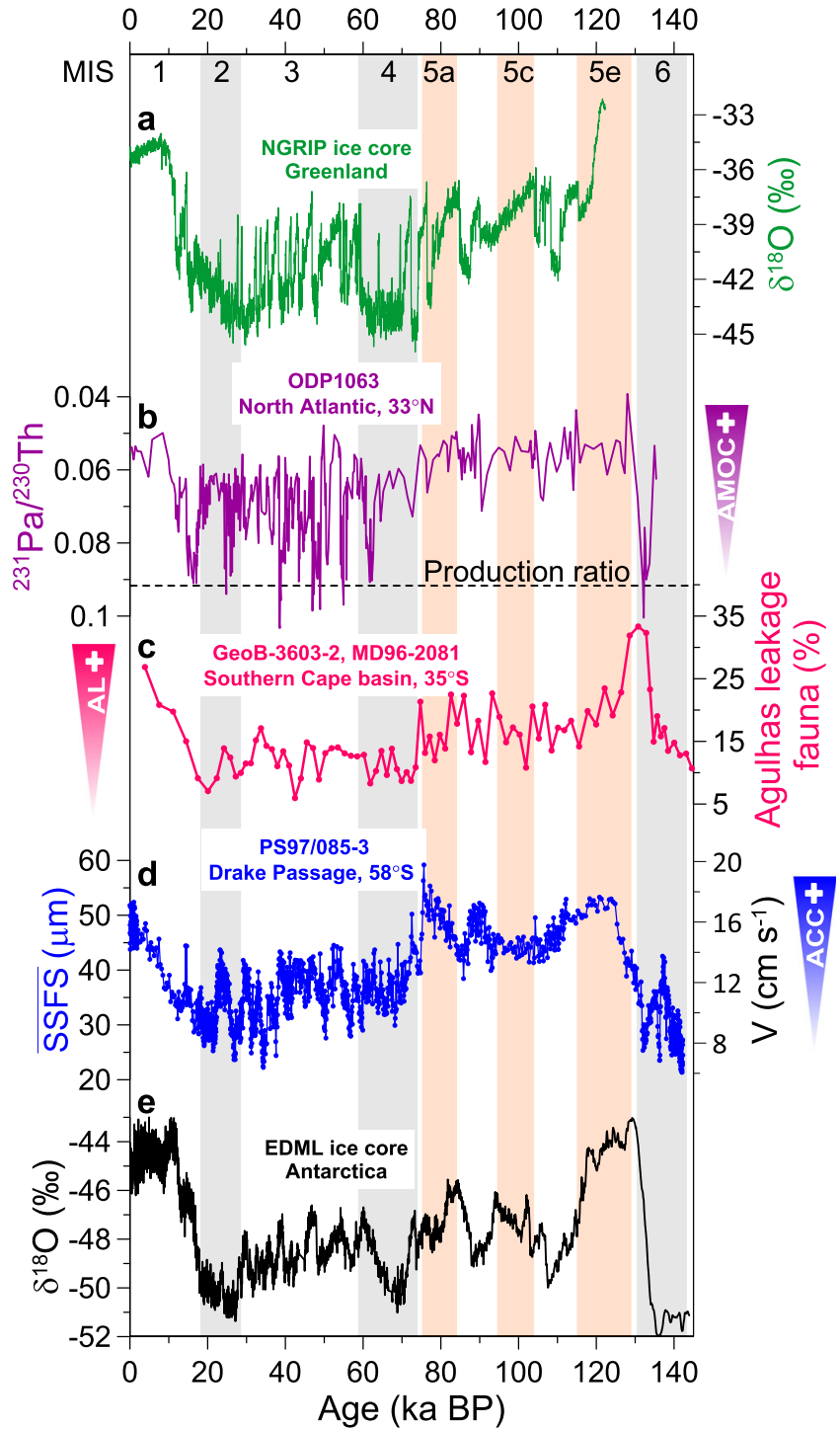

Fig. 5 Reconstructed changes in ACC strength compared with paleoclimatic records over the past 140 ka. a NGRIP oxygen isotope record ${ }^{70}$. b Bermuda Rise ${ }^{231} \mathrm{~Pa} /{ }^{230} \mathrm{Th}$ data $44,59,60$, indicating the AMOC strength. Dashed line is production ratio $\left({ }^{231} \mathrm{~Pa} /{ }^{230} \mathrm{Th}=0.093\right)$,

suggesting no transport. c Planktic foraminiferal fauna reflect the intensity of the Agulhas leakage ${ }^{58}$. d $\overline{\text { SSFS }}$ as a flow-speed proxy for the current strength (blue, this study) and the transferred ACC flow speeds. e Oxygen isotope record from the EDML ice core ${ }^{45}$. Vertical gray bars mark glacial periods and pink bars mark the warm stages during MIS 5.

higher ACC flow speeds during most of MIS 5 than the Holocene average (Fig. 5d). Such a strong ACC might have enhanced the formation of surface and intermediate water to fuel the upper overturning cell in the Southern Ocean during MIS 5. In contrast to the lower Agulhas leakage transport, the cold water route may have played a crucial role in keeping the AMOC vigorous throughout MIS 5. A slow-down of the ACC at the MIS 5/4 transition, followed by high frequency variations through MIS 4 to MIS 2, while a sluggish Agulhas leakage prevailed during the last glacial period ${ }^{58}$ (Fig. $5 c, d$ ). These strong variations of the ACC through the cold water route have been likely linked to high AMOC instability 46,48 between MIS 4 and MIS 2 (Fig. 5b).

Compared to the Holocene, our data imply a stronger ACC prevailed during the last, warmer-than-present interglacial ${ }^{35}$. This would be consistent with an overall stronger ACC together with 
strengthened westerly winds under warming climate ${ }^{2}$. Under warmer-than-present conditions, such a persistent cold water route return flow into the Atlantic could stabilize the AMOC in the long-term future, despite the AMOC showing emerging signs of weakening over the past decades ${ }^{65}$ and recently is at its weakest stage during the last millennium ${ }^{66}$. Although the ACC provided a dynamical link with the AMOC, several other important processes, like Southern Ocean wind-driven upwelling and buoyancy forcing $2,14,42$, may act together to explain the full changes of the AMOC.

\section{Methods}

Paleomagnetic measurements. Volume susceptibility on core PS97/085-3 was performed with a Bartington MS2E sensor and MS2 control unit on a split-core logger in $1 \mathrm{~mm}$ intervals and a sensor amplitude resolution of $10^{-5}$ (SI-Units). The slope of Natural remanent magnetization intensity versus anhysteretic remanent intensity of common demagnetization steps was determined in order to provide a proxy for the relative paleointensity (RPI) (see Supplementary Methods)

X-ray fluorescence core scanning (XRF-CS). The sediment core was measured with an AVAATECH XRF-CS at the Alfred Wegener Institute (AWI), Bremerhaven. XRF-CS data were collected in $1 \mathrm{~cm}$ steps (area $10 \times 12 \mathrm{~mm}$ ) along the core in three runs with $10 \mathrm{kV}, 30 \mathrm{kV}$, and $50 \mathrm{kV}$ (see Supplementary Methods).

Age model. The age model is based on a combination of radiocarbon dates, paleomagnetic excursion, correlation of RPI of core PS97/085-3 with the RPI stack and tuning from high resolution XRF-CS $\ln (\mathrm{Ca} / \mathrm{Ti})$ (Supplementary Table 1). Bayesian age-depth modeling program Bacon 2.3 was applied to develop an age model based on radiocarbon dates, paleomagnetic and tuning points (Supplementary Fig. 2). The error estimate (Supplementary Table 1) for tuning points and paleomagnetic tie points was done using mean squared estimate (details and reference see Supplementary Methods).

Grain-size measurements. A total of 1520 samples were taken in $1 \mathrm{~cm}$ intervals from core PS97/085-3 for grain-size measurements with a CILAS 1180L laser diffraction particle-size analyzer (CILAS, Orleans, France) at the AWI, Sylt. For comparison of different grain-size measurement methods, 80 samples were measured with a Micromeritics SediGraph 5100 at AWI, Bremerhaven (see Supplementary Methods and Supplementary Fig. 7).

Diatom census. The sample preparation of permanent mounted slides from core PS67/197-1 for microscopic diatom census followed the standard procedure established at the AWI ${ }^{67}$. Diatom species and species groups were identified and counted with a minimum of 400 specimens, at the magnification of $\times 1000$ using a Zeiss microscope. Relative abundances of sea ice related species Fragilariopsis curta and Fragilariopsis cylindrus were combined for estimation of changes in winter sea ice extent ${ }^{67}$ (Supplementary Fig. 8).

\section{Data availability}

All relevant data in this paper are available at PANGAEA Data Publisher (https://doi pangaea.de/10.1594/PANGAEA.923843).

Received: 7 September 2020; Accepted: 27 May 2021;

Published online: 24 June 2021

\section{References}

1. Marshall, J. \& Speer, K. Closure of the meridional overturning circulation through Southern Ocean upwelling. Nat. Geosci. 5, 171-180 (2012).

2. Rintoul, S. R. The global influence of localized dynamics in the Southern Ocean. Nature 558, 209-218 (2018).

3. Sigman, D. M. \& Boyle, E. A. Glacial/interglacial variations in atmospheric carbon dioxide. Nature 407, 859 (2000).

4. Gottschalk, J. et al. Biological and physical controls in the Southern Ocean on past millennial-scale atmospheric $\mathrm{CO}_{2}$ changes. Nat. Commun. 7, 11539 (2016).

5. McCave, I., Crowhurst, S., Kuhn, G., Hillenbrand, C. \& Meredith, M. Minimal change in Antarctic Circumpolar Current flow speed between the last glacial and Holocene. Nat. Geosci. 7, 113-116 (2014).

6. Lamy, F. et al. Glacial reduction and millennial-scale variations in Drake Passage throughflow. Proc. Natl Acad. Sci. USA 112, 13496-13501 (2015).
7. Roberts, J. et al. Deglacial changes in flow and frontal structure through the Drake Passage. Earth Planet Sc. Lett. 474, 397-408 (2017).

8. Toyos, M. H. et al. Antarctic Circumpolar Current dynamics at the Pacific entrance to the Drake Passage over the past 1.3 million years. Paleoceanogr. Paleoclimatol. 35, e2019PA003773 (2020).

9. Mazaud, A., Michel, E., Dewilde, F. \& Turon, J. Variations of the Antarctic Circumpolar Current intensity during the past $500 \mathrm{ka}$. Geochem. Geophys. Geosyst. https://doi.org/10.1029/2010GC003033 (2010).

10. Hall, I. R., McCave, I. N., Shackleton, N. J., Weedon, G. P. \& Harris, S. E. Intensified deep Pacfic inflow and ventilation in Pleistocene glacial times. Nature 412, 809-812 (2001).

11. Lynch-Stieglitz, J., Ito, T. \& Michel, E. Antarctic density stratification and the strength of the circumpolar current during the Last Glacial Maximum. Paleoceanogr. Paleoclimatol. 31, 539-552 (2016)

12. Williams, T. J. et al. Neodymium isotope evidence for coupled Southern Ocean circulation and Antarctic climate throughout the last 118,000 years. Quat. Sci. Rev. 260, 106915 (2021).

13. Diekmann, B. et al. In The South Atlantic in the Late Quaternary Ch. 4 (Springer, 2003)

14. Toggweiler, J. R., Russell, J. L. \& Carson, S. R. Midlatitude westerlies, atmospheric $\mathrm{CO}_{2}$, and climate change during the ice ages. Paleoceanogr. Paleoclimatol. https://doi.org/10.1029/2005PA001154 (2006).

15. Shi, J.-R., Talley, L. D., Xie, S.-P., Liu, W. \& Gille, S. T. Effects of buoyancy and wind forcing on southern ocean climate change. J Climate, https://doi.org/ 10.1175/JCLI-D-19-0877.1 (2020).

16. Martin, T., Steele, M. \& Zhang, J. Seasonality and long-term trend of Arctic Ocean surface stress in a model. J. Geophys. Res. Oceans 119, 1723-1738 (2014).

17. Orsi, A. H., Whitworth, T. III \& Nowlin, W. D. Jr On the meridional extent and fronts of the Antarctic Circumpolar Current. Deep Sea Res. Part I: Oceanographic Res. Pap. 42, 641-673 (1995).

18. Sokolov, S. \& Rintoul, S. R. Circumpolar structure and distribution of the Antarctic Circumpolar Current fronts: 1. Mean circumpolar paths. J. Geophys. Res. Oceans https://doi.org/10.1029/2008JC005108 (2009).

19. Rintoul, S. R. South Atlantic interbasin exchange. J. Geophys. Res. Oceans 96, 2675-2692 (1991).

20. Knorr, G. \& Lohmann, G. Southern Ocean origin for the resumption of Atlantic thermohaline circulation during deglaciation. Nature 424, 532 (2003).

21. Beal, L. M., De Ruijter, W. P. M., Biastoch, A., Zahn, R. \& Grp, S. W. I. W. On the role of the Agulhas system in ocean circulation and climate. Nature $\mathbf{4 7 2}$, 429-436 (2011).

22. Xiao, W., Esper, O. \& Gersonde, R. Last Glacial-Holocene climate variability in the Atlantic sector of the Southern Ocean. Quat. Sci. Rev. 135, 115-137 (2016).

23. Xiao, W. et al. Constraining the dating of late Quaternary marine sediment records from the Scotia Sea (Southern Ocean). Quat. Geochronol. 31, 97-118 (2016).

24. McCave, I. N. \& Hall, I. R. Size sorting in marine muds: processes, pitfalls, and prospects for paleoflow-speed proxies. Geochem. Geophy. Geosy. https://doi. org/10.1029/2006GC001284 (2006).

25. McCave, I. N., Manighetti, B. \& Robinson, S. G. Sortable silt and fine sediment size/composition slicing: parameters for palaeocurrent speed and palaeoceanography. Paleoceanogr. Paleoclimatol. 10, 593-610 (1995)

26. $\mathrm{Wu}, \mathrm{S}$. et al. Surface sediment characteristics related to provenance and ocean circulation in the Drake Passage sector of the Southern Ocean. Deep Sea Res. Part I: Oceanographic Res. Pap. 154, 103135 (2019).

27. Donohue, K., Tracey, K., Watts, D., Chidichimo, M. \& Chereskin, T. Mean antarctic circumpolar current transport measured in Drake Passage. Geophys. Res. Lett. https://doi.org/10.1002/2016GL070319 (2016).

28. McCave, I. N. \& Andrews, J. T. Distinguishing current effects in sediments delivered to the ocean by ice. I. Principles, methods and examples. Quat. Sci. Rev. 212, 92-107 (2019).

29. Fralick, P. W. \& Kronberg, B. I. Geochemical discrimination of clastic sedimentary rock sources. Sediment Geol. 113, 111-124 (1997).

30. Dypvik, H. \& Harris, N. B. Geochemical facies analysis of fine-grained siliciclastics using $\mathrm{Th} / \mathrm{U}, \mathrm{Zr} / \mathrm{Rb}$ and $(\mathrm{Zr}+\mathrm{Rb}) / \mathrm{Sr}$ ratios. Chem. Geol. 181, 131-146 (2001).

31. Wu, L. et al. Evaluating $\mathrm{Zr} / \mathrm{Rb}$ Ratio From XRF Scanning as an indicator of grain-size variations of glaciomarine sediments in the Southern Ocean. Geochem., Geophys. Geosyst. 21, e2020GC009350 (2020).

32. Walter, H., Hegner, E., Diekmann, B. \& Kuhn, G. Provenance and transport of terrigenous sediment in the South Atlantic Ocean and their relations to glacial and interglacial cycles: $\mathrm{Nd}$ and $\mathrm{Sr}$ isotopic evidence. Geochim Cosmochim. Acta 64, 3813-3827 (2000).

33. Diekmann, B. et al. Terrigenous sediment supply in the Scotia Sea (Southern Ocean): response to Late Quaternary ice dynamics in Patagonia and on the Antarctic Peninsula. Palaeogeogr. Palaeoclimatol. Palaeoecol. 162, 357-387 (2000). 
34. Fischer, $\mathrm{H}$. et al. Reconstruction of millennial changes in dust emission, transport and regional sea ice coverage using the deep EPICA ice cores from the Atlantic and Indian Ocean sector of Antarctica. Earth Planet Sc. Lett. 260, 340-354 (2007).

35. Shackleton, S. et al. Global ocean heat content in the Last Interglacial. Nat. Geosci. 13, 77-81 (2020).

36. Koenig, Z., Provost, C., Ferrari, R., Sennéchael, N. \& Rio, M.-H. Volume transport of the Antarctic Circumpolar Current: Production and validation of a 20 year long time series obtained from in situ and satellite observations. $J$. Geophys. Res. Oceans 119, 5407-5433 (2014).

37. Gersonde, R., Crosta, X., Abelmann, A. \& Armand, L. Sea-surface temperature and sea ice distribution of the Southern Ocean at the EPILOG Last Glacial Maximum-a circum-Antarctic view based on siliceous microfossil records. Quat. Sci. Rev. 24, 869-896 (2005).

38. Kohfeld, K. E. et al. Southern Hemisphere westerly wind changes during the Last Glacial Maximum: paleo-data synthesis. Quat. Sci. Rev. 68, 76-95 (2013).

39. Sime, L. C. et al. Southern Hemisphere westerly wind changes during the Last Glacial Maximum: model-data comparison. Quat. Sci. Rev. 64, 104-120 (2013).

40. Ferrari, R. et al. Antarctic sea ice control on ocean circulation in present and glacial climates. Proc. Natl Acad. Sci. USA 111, 8753-8758 (2014).

41. Markle, B. R., Steig, E. J., Roe, G. H., Winckler, G. \& McConnell, J. R. Concomitant variability in high-latitude aerosols, water isotopes and the hydrologic cycle. Nat. Geosci. 11, 853-859 (2018).

42. Anderson, R. F. et al. Wind-driven upwelling in the Southern Ocean and the deglacial rise in atmospheric $\mathrm{CO}_{2}$. Science 323, 1443-1448 (2009).

43. Lamy, F. et al. Modulation of the bipolar seesaw in the Southeast Pacific during Termination 1. Earth Planet Sc. Lett. 259, 400-413 (2007).

44. McManus, J. F., Francois, R., Gherardi, J. M., Keigwin, L. D. \& Brown-Leger, S Collapse and rapid resumption of Atlantic meridional circulation linked to deglacial climate changes. Nature 428, 834 (2004).

45. EPICA Community Members. One-to-one coupling of glacial climate variability in Greenland and Antarctica. Nature 444, 195-198 (2006).

46. Bond, G. et al. Evidence for massive discharges of icebergs into the North Atlantic ocean during the last glacial period. Nature 360, 245-249 (1992)

47. Jouzel, J. et al. Orbital and millennial Antarctic climate variability over the past 800,000 years. Science 317, 793-796 (2007).

48. Caniupan, M. et al. Millennial-scale sea surface temperature and Patagonian Ice Sheet changes off southernmost Chile (53 degrees S) over the past similar to 60 kyr. Paleoceanogr. Paleoclimatol. https://doi.org/10.1029/2010PA002049 (2011).

49. Gottschalk, J. et al. Abrupt changes in the southern extent of North Atlantic Deep Water during Dansgaard-Oeschger events. Nat. Geosci. 8, 950 (2015).

50. Collins, L. G., Pike, J., Allen, C. S. \& Hodgson, D. A. High-resolution reconstruction of southwest Atlantic sea-ice and its role in the carbon cycle during marine isotope stages 3 and 2. Paleoceanogr. Paleoclimatol. https://doi. org/10.1029/2011PA002264 (2012).

51. Holland, P. R. \& Kwok, R. Wind-driven trends in Antarctic sea-ice drift. Nat. Geosci. 5, 872-875 (2012).

52. Lüpkes, C., Gryanik, V. M., Hartmann, J. \& Andreas, E. L. A parametrization, based on sea ice morphology, of the neutral atmospheric drag coefficients for weather prediction and climate models. J. Geophys. Res. Atmos. https://doi. org/10.1029/2012JD017630 (2012).

53. Wilson, D. J. et al. Sea-ice control on deglacial lower cell circulation changes recorded by Drake Passage deep-sea corals. Earth Planet Sc. Lett. 544, 116405 (2020).

54. Huang, H., Gutjahr, M., Eisenhauer, A. \& Kuhn, G. No detectable Weddell Sea Antarctic Bottom Water export during the Last and Penultimate Glacial Maximum. Nat. Commun. 11, 1-10 (2020)

55. Yu, J. et al. Last glacial atmospheric $\mathrm{CO}_{2}$ decline due to widespread Pacific deep-water expansion. Nat Geosci. 13, 628-633 (2020).

56. Stein, K., Timmermann, A., Kwon, E. Y. \& Friedrich, T. Timing and magnitude of Southern Ocean sea ice/carbon cycle feedbacks. Proc. Natl Acad. Sci. USA 117, 4498-4504 (2020).

57. Rühs, S., Schwarzkopf, F. U., Speich, S. \& Biastoch, A. Cold vs. warm water route -sources for the upper limb of the Atlantic Meridional Overturning Circulation revisited in a high-resolution ocean model. Ocean Sci. 15, 489-512 (2019).

58. Peeters, F. J. et al. Vigorous exchange between the Indian and Atlantic oceans at the end of the past five glacial periods. Nature 430, 661 (2004).

59. Bohm, E. et al. Strong and deep Atlantic meridional overturning circulation during the last glacial cycle. Nature 517, 73-76 (2015).

60. Henry, L. G. et al. North Atlantic ocean circulation and abrupt climate change during the last glaciation. Science 353, 470-474 (2016).

61. Caley, T. et al. Quantitative estimate of the paleo-Agulhas leakage. Geophys Res Lett. 41, 1238-1246 (2014).

62. Koenig, Z., Provost, C., Park, Y.-H., Ferrari, R. \& Sennéchael, N. Anatomy of the Antarctic Circumpolar Current volume transports through Drake Passage. J. Geophys. Res.: Oceans 121, 2572-2595 (2016).
63. Artana, C. et al. Twenty-five years of Mercator ocean reanalysis GLORYS12 at Drake Passage: Velocity assessment and total volume transport. Adv Space Res. 68, 447-466 (2019)

64. Drouin, K. L. \& Lozier, M. S. The surface pathways of the South Atlantic: revisiting the cold and warm water routes using observational data. J. Geophys. Res. Oceans 124, 7082-7103 (2019)

65. Srokosz, M. \& Bryden, H. Observing the Atlantic Meridional Overturning circulation yields a decade of inevitable surprises. Science 348, 1255575 (2015).

66. Caesar, L., McCarthy, G. D., Thornalley, D. J. R., Cahill, N. \& Rahmstorf, S. Current Atlantic Meridional Overturning Circulation weakest in last millennium. Nat Geosci. https://doi.org/10.1038/s41561-021-00699-z (2021).

67. Gersonde, R. \& Zielinski, U. The reconstruction of late Quaternary Antarctic sea-ice distribution-the use of diatoms as a proxy for sea-ice. Palaeogeogr., Palaeoclimatol., Palaeoecol. 162, 263-286 (2000).

68. Comiso, J. C. in Sea Ice: An Introduction to Its Physics, Chemistry, Biology and Geology Ch. 4 (Blackwell Science, Oxford, 2003).

69. Meredith, M. P. et al. Sustained monitoring of the Southern Ocean at Drake Passage: past achievements and future priorities. Rev. Geophys. https://doi.org/ 10.1029/2010RG000348 (2011).

70. Andersen, K. K. et al. High-resolution record of Northern Hemisphere climate extending into the last interglacial period. Nature 431, 147-151 (2004).

\section{Acknowledgements}

We thank the captain, crew and scientific party of RV Polarstern Expedition PS97 for their professional help in retrieving the sediment samples. We also thank C. Lange, X. Gong, and A.C. Ravelo for discussions. We sincerely thank S. Wiebe and R. FröhlkingTeichert at the AWI for technical assistance in sample preparation, grain-size measurements, and XRF scans. Klinikum Bremen-Mitte and A.-J. Lemke and C. Tiemann, Gesundheit Nord Bremen, are gratefully acknowledged for providing facilities and supporting the computed tomography measurements. This study was supported by the Alfred Wegener Institute Helmholtz Centre for Polar and Marine Research research programmes "Polar Regions and Coasts in the changing Earth System" (PACES II), "Ocean and Cryosphere in Climate" (Topic2, PoF IV) and the China Scholarship Council (CSC No. 201604910671). X. Zheng is supported by the National Natural Science Foundation of China (41776061, 91958106, 41876068), Pearl River S\&T Nova Program of Guangzhou (201906010050), and the Special Support Program for Training HighLevel Talents in Guangdong (2019TQ05H572). J. Titschack acknowledges funding by the MARUM DFG-Research Center/Excellence Cluster "The Ocean in the Earth System". We acknowledge support by the Open Access Publication Funds of AlfredWegener-Institut Helmholtz-Zentrum für Polar- und Meeresforschung.

\section{Author contributions}

S.W. together with L.L.J., F.L., and G.K. led the research. S.W. carried out high-resolution grain-size measurements and together with G.K and H.C.H. analyzed the data. L.D. performed additional sortable silt measurements. J.T. led CT scanning and processed data with S.W., H.W.A., and G.K. contributed XRF core scanning and magnetic susceptibility data. X.F.Z. and J.L carried out magnetic property measurements. L.L.J. contributed ${ }^{14} \mathrm{C}$ data. H.W.A., N.N., F.L., and S.W. generated age model. W.X. carried out diatom counts for sea ice reconstruction. X.Z. helped shape the initial concept and contribute to data interpretation. S.W. wrote the manuscript with contribution from L.L.J., F.L., and G.K. All the co-authors contributed to the interpretation of the results and provided inputs to the final version.

\section{Funding}

Open Access funding enabled and organized by Projekt DEAL.

\section{Competing interests}

The authors declare no competing interests.

\section{Additional information}

Supplementary information The online version contains supplementary material available at https://doi.org/10.1038/s41467-021-24264-9.

Correspondence and requests for materials should be addressed to S.W.

Peer review information Nature Communications thanks Lionel Carter and Aidan Starr for their contribution to the peer review of this work.

Reprints and permission information is available at http://www.nature.com/reprints

Publisher's note Springer Nature remains neutral with regard to jurisdictional claims in published maps and institutional affiliations. 
(c) (i) Open Access This article is licensed under a Creative Commons Attribution 4.0 International License, which permits use, sharing, adaptation, distribution and reproduction in any medium or format, as long as you give appropriate credit to the original author(s) and the source, provide a link to the Creative Commons license, and indicate if changes were made. The images or other third party material in this article are included in the article's Creative Commons license, unless indicated otherwise in a credit line to the material. If material is not included in the article's Creative Commons license and your intended use is not permitted by statutory regulation or exceeds the permitted use, you will need to obtain permission directly from the copyright holder. To view a copy of this license, visit http://creativecommons.org/ licenses/by/4.0/.

(c) The Author(s) 2021, last corrected publication 2022 